\title{
Anencephaly associated with cleft palate in a Bull Terrier litter: case report
}

\author{
Marcelline Santos Luz ${ }^{1,2}$,Denise de Mello Bobány ${ }^{1}$,Maria Eduarda Monteiro \\ Silva ${ }^{1}$, Carla FernandaMoura Carvalho ${ }^{3}$ \\ ${ }^{1}$ Unifeso- Centro Educacional Serra dos Órgãos- Teresópolis-Rio de Janeiro-Brasil \\ ${ }^{2}$ Vidalltech Biotecnologia e Reprodução Animal-Teresópolis-Rio de Janeiro-Brasil \\ ${ }^{3}$ UFRRJ- Universidade Federal Rural do Rio de Janeiro-Brasil
}

\begin{abstract}
The anencephalyisrare in veterinary medicine. This anomaly may be diagnosed by ultrasound, radiography, fetoscopy and more recently by omputed to mography and magneticresonance imaging. The objective of this study was to describe the findings ultrasound performed in thepre-christmasof a bitch Bull Terrierprimiparous, where it waspossibleto diagnose anencephaly in sevenfetuses. The findings high lighted the importance of imaging diagnos is methods for the determination of the anencephaly of dogs.
\end{abstract}

Keywords: anencephalic fetus, congenital anomalies, dog, morphogenesis, palatoschisis

\section{Introduction}

Infectious agents, toxic plants, chemicals, physical aggression or nutritional deficiencies may cause congenital abnormalities. However, some defects can occur without a specific cause [1].

According to Dias et al. [2] and Saraiva [3], the nervous system isoften affected with generally arising defects during morphogenesis, as well as resulting from exposure during the prenatal and perinatal period, teratogenic agents and sometimes can be hereditary.Anencephaly can be defined as a complete or partial absence of the brain and skull bone, which develops a defect in the cranial portion of the neural tube $[4,5,6,7,8]$.

Dewey and Costa [8] reportes that the dogs carriers of these defects usually are stillborn or die soon after birth, and if not, are euthanized promptly. The palatoschisis characterized by cleft palate and incomplete closure of the palate [8,9] and, according Berghe et al .[9], there is possibility of having a hereditary cause involved.During the period of development of the fetus has been possible through the ultrasound to identify the bones of the skull between days 30 and 35 of gestation, although there is not yet bearing mineralizados. The cavities of the brain are observed between the days 40 and 50 of gestation [10].

According to Martini-Santos et al. [1], congenital anomalies in carnivores are poorly reported and of uncertain etiology.Thus, the objective of this study was to describe the findings ultrasound performed in the prechristmas of a bitch Bull Terrier, where it was possible to diagnose anencephaly in seven fetuses, highlighting the importance of imaging diagnosis methods for the determination of anencefalia in dogs and contribute with a little more data for the scientific literature to future research in the area of birth defects.

\section{Case Report and Discussion}

A Bull Terrier female,primiparous, 2 years old, was artificially inseminated with fresh semen and submitted to ultrasonographic examination to confirm pregnancy 30 days after insemination. At this examination were visualized seven viable fetuses without apparent abnormalties.

At 50 days was made a new ultrasonography; method recommended by Veiga, Souza, Vieira[11] and Bomfim et al. [12], which revealed anomalous aspect of the skull of the fetus and apparently increased volume of amniotic fluid.The dog went into labor at 62 days, but could not give birth. New ultrasound was taken and wasfound fetal distress.The cesareansectionwasperformedand it wasobservedthatthesevenpuppies (femaleand male) had no skullandbrainmasswasexposed (Fig. 1), and each one of thefetuseswasalsosufferingfromcleft palate and hiperglossia(Fig.2) as reported by Berghe et al. [9], Huisinga et al. [5], Lahunta, Glass, Kent [6] and Dewey, Costa [8].The ultrasound was a good method of assessing gestational age, to identify the number of fetuses, as well as determination of the malformation, anencephaly, as described by Jarreta (10).

The female was hysterectomized after cesarean section. The uterus was severely distended with fluid and had no contraction.The fetuses were sacrificed soon after birth according to Dewey and Costa [8]. 


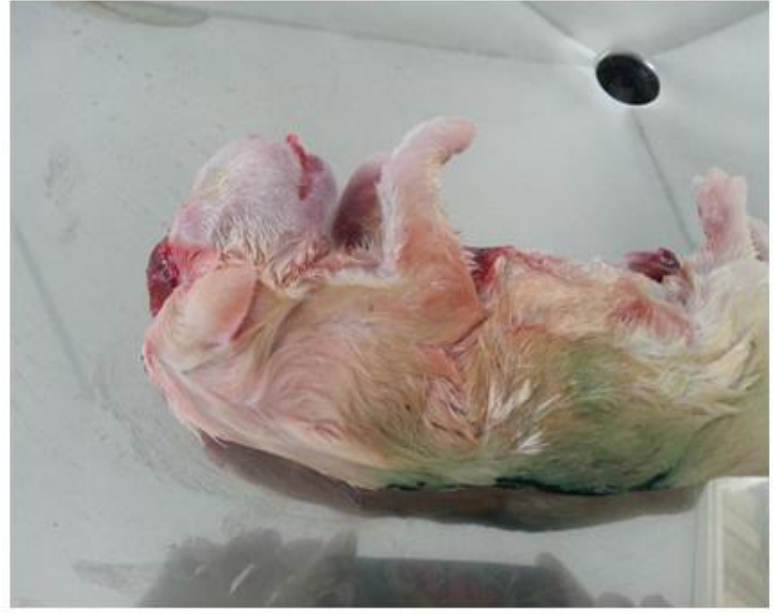

Figure 1 - Image of one of the fetuses showing the skinandcalvariumnotcloseddorsally

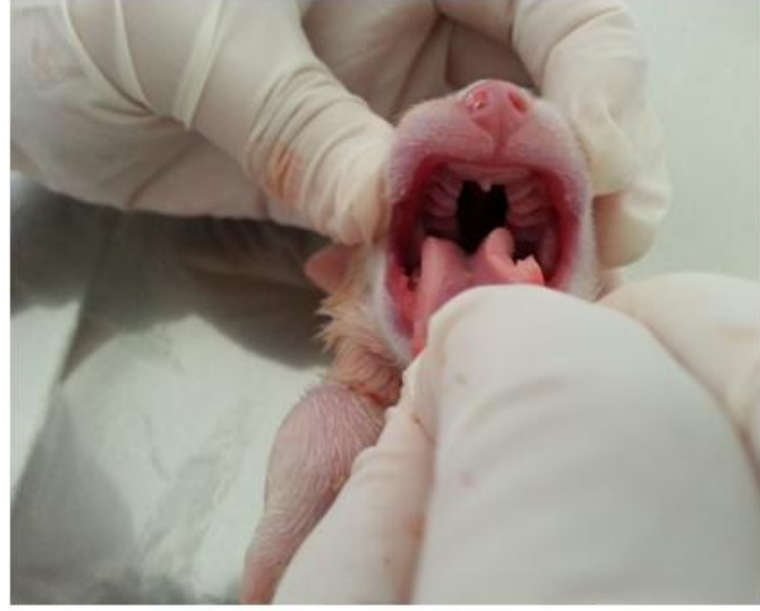

Figure 2 - Imageofoneofthefetuses showing the cleft palate

Seeking explanations for the causes of what happened among some causes of anencephaly whit cleft palate, many hypotheses are possible but, according to Martini-Santos et al. [1], Dias et al. [2] and Saraiva [3], the defects can occur without a specific cause.

The female was in good general condition, without knowledge of history of malformations among relatives. The stud dog is admittedly fertile and with a history of numerous and normal litters, which leads us to wonder about the possible cause of this malformation. These fetuses, presented associated cleft palate and hiperglossia in all seven puppies, fact with no previous reports in the literature.

Bull Terriers displays a history of family illness as Acrodermatitis Lethal related thymic hypoplasia, with decreased plasma zinc levels, recessive autosomal frequency, according to Smits, Croft, Abrams-Ogg[13] and Bellah, Smith [14].

In this case, not cogitated make plasma zinc dosage, which fall the concentration of this element could allow an analogy with the human species, as in cases of maternal zinc deficiency as one of the factors responsible for neural tube defects in fetuses in Turkey, according Cavdar et al. [15].

\section{Conclusions}

The case of anencephaly in all seven fetuses of the bitch of the breed Bull Terrier has no similar in the literature. The various hypotheses for the cause of this serious event lead us to various possibilities and suggest further deepening in the studies and notifications. Ultrasound has helped in the identification of the anencephaly.

Studies with embryonic malformations in dogs are needed to determine the true importance of these malformations and if there is triggering factors.

\section{Referências}

[1] B.J. Martini-Santos, A. Diefenbach, T.C. Peixoto, J.E. Nóbrega Jr., B.L. Anjos, Anomalias congênitas múltiplas em felinos domésticos neonatos. AS Veterinariae40(4), 2012, 1087.

[2] L.G.G.G. Dias, F.G.G. Dias, F.M.Ikenaga, C.S.Honsho, F.F. Souza, A.L.Selmi, E. Mattos Junior, Palatoplastia com retalho sobreposto em cão - Relato de caso. RevBrasMedVet37(3), 2015, 179-185.

[3] C.R. Saraiva. Hidrocefalia em canídeos: a propósito de dezesseis casos clínicos, doctoraldiss.,Lisboa FMV-Universidade de Lisboa, 2016.

[4] J.A Santos. Patologia especial dos animais domésticos (mamíferos e aves) (Rio de Janeiro: Instituto Interamericano de CienciasAgricolas- OEA, 1975).

[5] M. Huisinga, M. Reinacher, S.Nagel, C. Herden, Anencephaly in a GermanShepherd Dog. VetPathol47(5), 2010, 948-951.

[6] A. Lahunta , E.N.Glass, M. Kent, Veterinary Neuroanatomy and Clinical Neurology (Amsterdam: Elsevier Health Sciences, 2014).

[7] C. Cantile, S. Youssef, Nervous System, in K.V.F. Jubb, P.C. Kennedy, N. Palmer, Pathology of Domestic Animals, 6 (Amsterdam: Elsevier Health Sciences, 2015) 250-283.

[8] C.W. Dewey, R.C. Costa, Practical Guide to Canine and Feline Neurology (Nova Jersey, EUA: John Wiley \& Sons, 2015).

[9] F.V. Berghe, P. Cornillie, L. Stegen, B.V. Goethem, P. Simoens, Palatoschisis in the dog: developmental mechanisms and etiology. VlaamsDiergenTijds79, 2010, 117-123.

[10] Jarreta G.B. Ultra-sonografia do aparelhoreprodutorfeminino, inCarvalho C.F. (Ed.), Ultra-SonografiaemPequenosAnimais. (Roca Editora, São Paulo, 2004) 181-212.

[11] C.C.P. Veiga, B.G. Souza, S.L. Vieira, Avaliações prénatal ultrassonográfica e radiográfica no diagnóstico de anencefalia em cão relato de caso. RevBrasMedVet 35(2), 2013, 101-4.

[12] P.C. Bomfim, C.C.P. Veiga, S.L. Vieira, R.L. Moraes, P.J. Nunes, F.O.Gomes, Avaliações ultrassonográfica pré-natal e radiográfica no diagnóstico de anencefalia em cão - relato de caso. Arch Vet Sci19 (supl.), 2014. 
[13] B. Smits, D.L. Croft, O.G.G. Abrams, C.G. Anthony, Lethal acrodermatitis in bull terriers: a problem of defective zinc metabolism.Vet Dermatol2(2), 1991,91-5.

[14] J.R. Bellah, A.N. Smith ,The Thymus. inD.H..Slatter, Textbook of Small Animal Surgery, 3(Amsterdam: Elsevier Health Sciences, 2003) 1083-1089.

[15] A.O. Cavdar, M. Bahçeci, N. Akar, J. Erten, G. Bahçeci, E. Babacan, A. Arcasoy, H. Yavuz, Zinc status in pregnancy and the occurrence of anencephaly in Turkey. J Trace Elem Elect H 2(1), 1988, 9-14. 